\title{
Natural Remanent Magnetization of Tertiary Plutonic Rocks affected by Tectonic Movement of Land Mass in Central Japan
}

\author{
By Haruaki ITO \\ Physics Laboratory, Shimane Agricultural College \\ (Read May, 13, 1963; Recieved May, 15, 1963)
}

\begin{abstract}
About 100 samples were collected from 12 outcrops of Tertiary plutonic rocks in 5 localities distributed over the central part of Honshu, Japan, and their natural remanent magnetization (n.r.m.) were measured. The results of the measurements were classified into three groups: (1) the n.r.m. parallel to the present dipole field, (2) the n.r.m. along the direction of $\mathrm{N} 20^{\circ} \mathrm{E}$ and (3) the n.r.m. along the direction of $\mathrm{N} 31^{\circ} \mathrm{W}$.

The central part of Honshu had been subjected to tectonic activities in Tertiary age and the intrusions of plutonic rocks were associated with these activities. Some of these intrusion seems to have been affected by the tectonic movements and moved in different ways after the solidification. The sites, from where the rock samples were collected, are located over 5 different intrusions and the difference of the directions of the n.r.m. mentioned above can be explained by the relative movement of these intrusions.
\end{abstract}

\section{Introduction}

There are many examples of the application of rock magnetism to the geological problems. The most well-known example is that applied to the continental drift in which the relative movements of continents through the geological age are quantitatively estimated by comparing the direction of the natural remanent magneization (n.r.m.) of rocks collected from different continents in the world (Collinson and Runcorn, 1960 ; Irving, 1956; Blackett et al, 1960). The results of the measurements of the n.r.m. are also used to explain the formation of the Isle and Arc such as the formation of the Japanese Islands (Kawai et al, 1961). It is possible to apply the results of the palaeomagnetic measurements to the interpretation of other kinds of geological phenomena, some of the examples being given by Doell and Cox (1960), and also by Blundell (1961).

The Japanese Islands are situated in the orogenic zone surrounding the Pacific Ocean and they had been subjected to the various kinds of tectonic movements and the present geological structure of the Japanese Islands is believed to have been formed at the period of the early or middle Tertiary age. Kawai, Kume and the author (1961, 1962) measured the n.r.m. of the rocks of Mesozoic and Cenozoic eras collected all over Honshu (main island of Japan) to find a systematic difference in the direction in the 
northeastern and southwestern parts of Honshu. To explain this pesult, they proposed a possibility of the bend of the Japanese Islands, concluding that the relative bending of the northeastern and the southwestern parts had reached about $45^{\circ}$ by the beginning of Tertiary age.

The boundary region by which Honshu is divided into the northeastern and the southwestern parts is known as "fossa magna" and this region has also been submitted by tectonic movements in Mesozoic and in Tertiary age, and several plutonic activities accompanied by these movements are observed. However, the mechanism of these

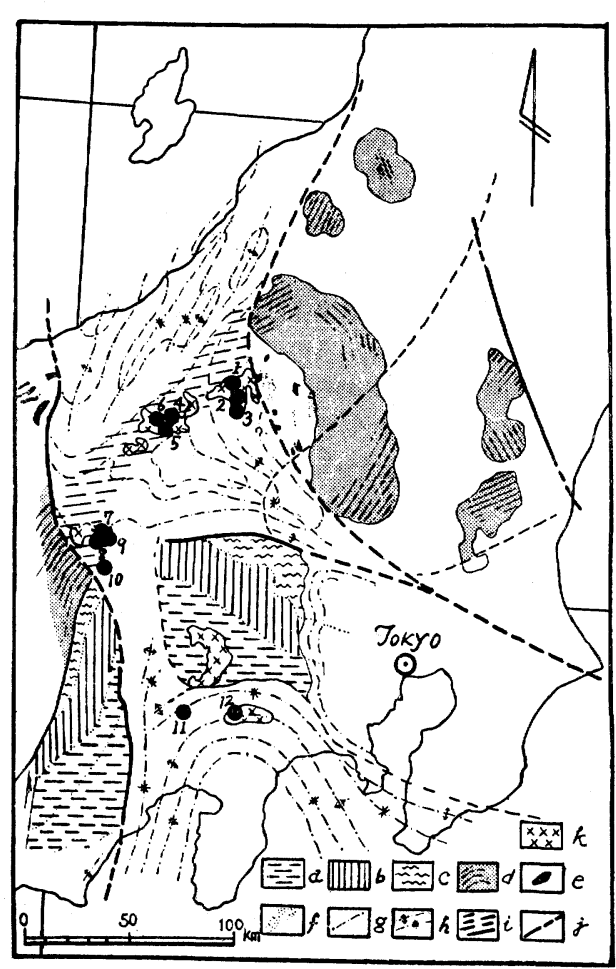

Fig. 1. Geological structural map of the fossa magna (after Omori).

Collecting sites of rock samples are shown herein by the numbers from 1 to 12 corresponding to Table 1.

a: Shimanto zone (Mesozoic and Palaeogine formations)

b: Chichibu zone (Palaeozoic system)

c: Sambagawa zone (Metamorphosed Palaeozoic system)

d: Non-metamorphosed Palaeozoic formation

e: Serpentine

f: Katashinagawa tectonic zone

$\mathrm{g}$ : General trend of Tertiary sediments

$\mathrm{h}$ : Axis of folding

i : Murasame zone

j: Tectonic line

$\mathrm{k}$ : Acidic plutonic rocks of Tertiary age activities has not been elucidated from the geological evidences and the measurement of the n.r.m. seems to be a good method to make the detail clear. For this purpose, the author collected about 100 plutonic rocks from 5 localities in the fossa magna and found a difference in the direction of the n.r.m. at each locality. He will show that this difference is explained by assuming a relative movement of local land mass which affected the direction of the n.r.m. of these rocks.

\section{Geological Significance of Tertiary} Plutonic Rocks in Central Honshu

About 100 samples of the Tertiary plutonic rocks which extend over the wide area in central part of Honshu were collected from 5 localities (Fig. 1).

a) Shimizu Tunnel District, Niigata Prefecture

Rock kind in this district is quartz diorite which was intruded into the lower Miocene sediment. Therefore its age is younger than lower Miocene, although the precise age of intrusion is not known (Toyota, 1931). 26 samples were collected from 3 sites in this district (Table 1 and Fig. 1).

b) Suzaka District, Nagano Prefecture By the geological surveys (Ota and Katada, 1955), plutonic rocks in this district had been intruded after the formation of sedimentary rocks in Neogene. Subsequently, volcanic rocks erupted and covered 
Table

\begin{tabular}{|c|c|c|c|c|c|}
\hline Locality & Collecting Sites & Rock Kind & $\begin{array}{l}\text { Number of } \\
\text { Stable } \\
\text { Specimens }\end{array}$ & $\begin{array}{l}\text { Number of } \\
\text { Unstable } \\
\text { Specimens }\end{array}$ & $\begin{array}{l}\text { Number of } \\
\text { Specimens } \\
\text { having no } \\
\text { n.r. m. }\end{array}$ \\
\hline $\begin{array}{l}\text { Shimizu Tunnel } \\
\text { District }\end{array}$ & $\begin{array}{ll}1 & \text { Tsuchitaru } \\
2 & \text { Doai } \\
3 & \text { Minakami }\end{array}$ & $\begin{array}{c}\text { Quartz Diorite } \\
\text { ditto } \\
\text { ditto }\end{array}$ & $\begin{array}{r}16 \\
4 \\
\end{array}$ & {[} & $-\overline{-}$ \\
\hline Suzaka District & $\begin{array}{ll}4 & \text { Sennin } \\
5 & \text { Iwato } \\
6 & \text { Haccho }\end{array}$ & $\begin{array}{l}\text { Quartz Porphyry } \\
\text { Granite Porphry } \\
\text { Grano-diorite }\end{array}$ & $\begin{array}{r}3 \\
5 \\
\end{array}$ & $\overline{6}$ & $\overline{-}$ \\
\hline $\begin{array}{l}\text { Lake Suwa } \\
\text { District }\end{array}$ & $\begin{aligned} 7 & \text { Ode } \\
8 & \text { Omeguraguchi } \\
9 & \text { Omegura } \\
10 & \text { Kamisuwa }\end{aligned}$ & $\begin{array}{l}\text { Quartz Diorite } \\
\text { ditto } \\
\text { ditto } \\
\text { ditto }\end{array}$ & $\begin{array}{r}2 \\
14 \\
\end{array}$ & $\begin{array}{c}\overline{5} \\
5 \\
5\end{array}$ & $\begin{array}{r}2 \\
3 \\
\end{array}$ \\
\hline Kofu District & 11 Ichikawadaimon & Gabbro & 8 & - & - \\
\hline Tanzawa District & 12 Yamabushi-toge & Quartz Diorite & 11 & - & - \\
\hline
\end{tabular}

both plutonic and sedimentary rocks in some time between Neogene and Quaternary. The plutonic rocks here seem to have been intruded at the time of Miocene. 16 samples were collected from 3 sites in this locality (Table 1 and Fig. 1).

c) Lake Suwa District, Nagano Prefecture

Intrusive rocks of grano-diorite, metadiabase and quartz diorite porphyrite are found in this area and their ages seem to be Miocene, since they were intruded into Moriya formation which considers to have occured in Miocene and were covered with volcanic rocks of Quaternary (Sawamura and Owa, 1953). In this district, 31 samples were collected from 4 sites (Table 1 and Fig. 1).

d) Kofu District, Yamanashi Prefecture

The time of the intrusion of plutonic rocks in this area seems to be contemporaneous with that of the Ichikawadaimon and the Kawaguchi formations. There are three kinds of the plutonic rocks in this region, Mesozoic granite, Tertiary granite and gabbro (Katada, 1956). 8 gabbro samples were collected from one site in this locality (Table 1 and Fig. 1).

e) Tanzawa Mountain District, Yamanashi Prefecture

In this district, quartz diorite had been intruded into the Misaka formation, which deposited at the beginning of Miocene and was metamorphosed by the intrusion. The time of the intrusion appears to be middle Miocene (Morishita, 1934). Morishita studied the tectonic movement during and after the intrusion, showing some evidences such as the existence of lineation or joint structure inside the rocks. 11 samples were collected from here (Table 1 and Fig. 1).

As seen from the geological surveys on each locality, those plutonic rocks are considered to have been intruded some time in Miocene times.

\section{Results of the Measurement of the n.r.m.}

The directions and intensities of the n.r.m. were measured with the high sensitive 
astatic magnetometer (Kawai, 1951). As there had been found some rocks with no n.r.m. or unstable n.r.m., the specimens were measured in 1957 at first and remeasured in 1962 after having been stored in random directions in the laboratory for five years. The n.r.m. which showed a large change in remeasurement was regarded as unstable.

After omitting the specimens with the unstable n.r.m., two specimens from each locality were chosen to test the stability in A.C. field. In A.C. fiield up to 300 oe, the intensity of the n.r.m. decreased to $75 \%$ of the initial values, whereas the change in direction was within a few degrees. Therefore, the specimens whose n.r.m. had shown

Table 2

\begin{tabular}{|c|c|c|c|c|c|c|c|c|c|c|c|}
\hline \multirow[t]{2}{*}{ Locality } & \multirow{2}{*}{$\begin{array}{c}\text { Number } \\
\text { of } \\
\text { Speci- } \\
\text { mens }\end{array}$} & \multirow[t]{2}{*}{ Age } & \multirow[t]{2}{*}{$\begin{array}{l}\text { Rock } \\
\text { Kind }\end{array}$} & \multicolumn{2}{|c|}{$\begin{array}{c}\text { Mean } \\
\text { Direction } \\
\text { of n.r.m. }\end{array}$} & \multicolumn{2}{|c|}{$\begin{array}{c}\text { Pole } \\
\text { Position }\end{array}$} & \multirow{2}{*}{$\begin{array}{l}\text { Intensity } \\
\text { of n.r.m. } \\
\text { (e.m.u. } \\
\text { /gr.) }\end{array}$} & \multirow{2}{*}{$\begin{array}{c}\text { Induced } \\
\text { Magnetiza- } \\
\text { tion in } 0.3 \text { oe } \\
\text { (e.m.u./gr.) }\end{array}$} & \multirow[t]{2}{*}{$Q$} & \multirow{2}{*}{$\begin{array}{l}\text { Circle } \\
\text { of Con- } \\
\text { fidence } \\
(5 \%)\end{array}$} \\
\hline & & & & Decl. & Incl. & Lat. 1 & Long. & & & & \\
\hline $\begin{array}{l}\text { Shimizu } \\
\text { Tunnel } \\
\text { District }\end{array}$ & 20 & Miocene & $\begin{array}{l}\text { Quartz } \\
\text { Diorite }\end{array}$ & $\mathrm{N} 3^{\circ} \mathrm{E}$ & $+52^{\circ}$ & $87^{\circ} \mathrm{N}$ & $134^{\circ} \mathrm{W}$ & $1.65 \times 10^{-4}$ & $1.85 \times 10^{-4}$ & 0.89 & $7.2^{\circ}$ \\
\hline $\begin{array}{l}\text { Suzaka } \\
\text { District }\end{array}$ & 8 & ," & $\begin{array}{l}\text { Quartz } \\
\text { Porphry }\end{array}$ & $\mathrm{N} 20^{\circ} \mathrm{E}$ & $+55^{\circ}$ & $74^{\circ} \mathrm{N}$ & $132^{\circ} \mathrm{W}$ & 1.25 & 0.78 & 1.60 & $7.6^{\circ}$ \\
\hline $\begin{array}{l}\text { LakeSuwa } \\
\text { District }\end{array}$ & 16 & ", & $\begin{array}{l}\text { Quartz } \\
\text { Diorite }\end{array}$ & $\mathrm{N} 31^{\circ} \mathrm{W}$ & $+45^{\circ}$ & $62^{\circ} \mathrm{N}$ & $59^{\circ} \mathrm{E}$ & 0.93 & 2.43 & 0.38 & $9.3^{\circ}$ \\
\hline $\begin{array}{l}\text { Kofu } \\
\text { District }\end{array}$ & 8 & ", & Gabbro & $\mathrm{N} 3^{\circ} \mathrm{W}$ & $+45^{\circ}$ & $81^{\circ} \mathrm{N}$ & $122^{\circ} \mathrm{W}$ & 8.57 & 2.69 & 3.07 & $5.9^{\circ}$ \\
\hline $\begin{array}{l}\text { Tanzawa } \\
\text { District }\end{array}$ & 11 & ", & $\begin{array}{l}\text { Quartz } \\
\text { Diorite }\end{array}$ & $\mathrm{N} \quad 1^{\circ} \mathrm{W}$ & $+52^{\circ}$ & $89^{\circ} \mathrm{N}$ & $132^{\circ} \mathrm{W}$ & 1.94 & 3.71 & 0.52 & $12.4^{\circ}$ \\
\hline
\end{tabular}
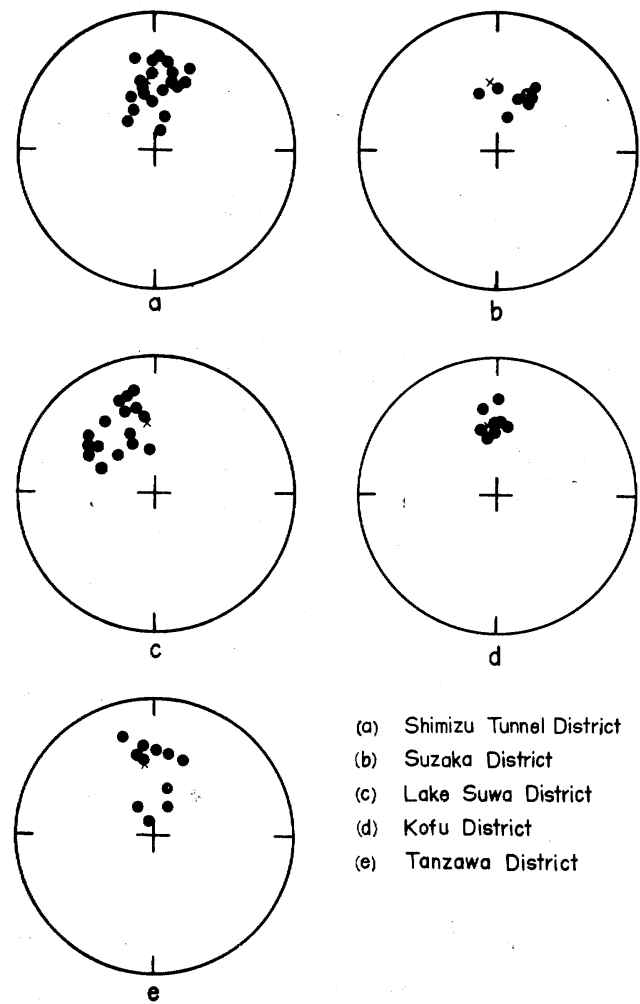

(a) Shimizu Tunnel District

(b) Suzaka District

(c) Lake Suwa District

(d) Kofu District

(e) Tanzawa District

Fig. 2. Directions of n.r.m. plotted on Schmidt equal area projections.

$x$ : Direction of the present dipole field

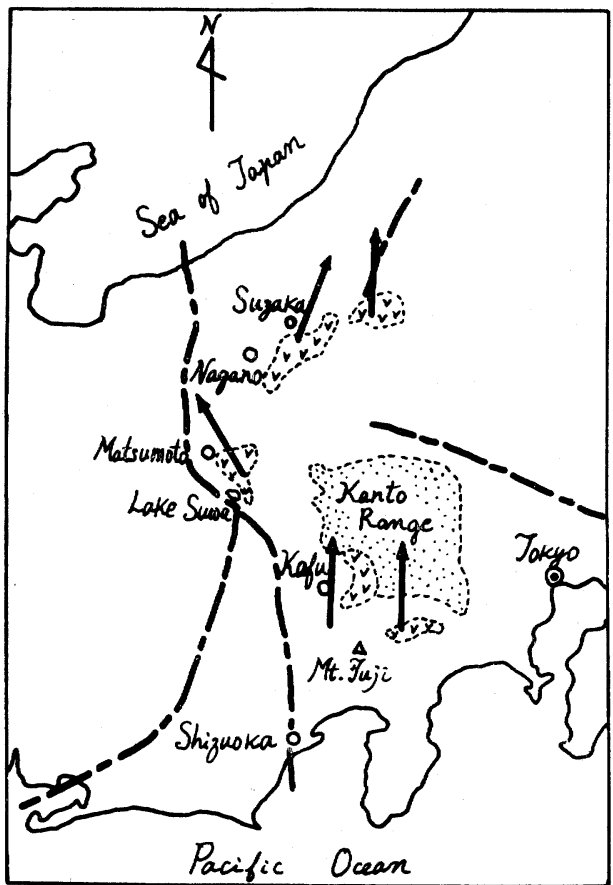

Fig. 3. Mean directions of n.r.m. averaged in each locality and plotted on the map of the fossa magna zone. 
no change for five years seem to possess the stable n.r.m. even in A.C. field of 300 oe. The numbers of specimens with stable, unstable and no n.r.m. are tabulated in Table 1 and the results of the measurements of the stable n.r.m. are tabulated in Table 2 and the directions of the stable n.r.m. are shown in Fig. 2.

\section{Interpretation of the Results and Conclusion}

The central part of Honshu is known by the name "fossa magna" zone, and many tectonic movements and igneous activities since Mesozoic era have been observed here. Kobayashi (1941) stated that a north region of Kanto Range shifted eastwards relative to the Kanto Range. Ehara (1956) pointed out that the western part of the Kanto Range was moved northwards due to the pushing force generated by the displacement of a batholith in the Pacific Ocean.

The mean directions of the n.r.m. averaged in each locality are plotted on the map of the fossa magna in Fig. 3. As seen in this figure, the directions at the localities, Shimizu Tunnel, Tanzawa and Kofu, are parallel to that of the present dipole field, other two being deviated from that. There are two possibilities to produce this deviation.

a) There has been no tectonic movement of these plutonic rock blocks, but the past geomagnetic field had changed from time to time, the direction of the n.r.m. being a faithful record of the past geomagnetic field at each age.

b) The geomagnetic field has been almost parallel to the present one after the first intrusion of these plutonic rocks and some of the blocks of the plutonic rocks rotated relative to each other, the amount of the rotation being represented by the angle of the deviation from the direction of the present dipole field.

As stated in $\S 1$, all of these rocks consider to have formed in Miocene times. The palaeomagnetic results obtained in the world so far indicate that the pole position in Miocene had approximated to the present one (Doell and Cox, 1961). Moreover, there are many evidences which suggest the relative movement of land mass in this region in question (Omori, 1960; Research group of the fossa magna, 1958). Although some small change of the geomagnetic field must have occurred in Miocene, it is more likely that the case (b) took place in some time after the solidification of the intrusion of the plutonic rocks and also after the acquisition of the n.r.m..

The mean direction of the n.r.m. of the samples collected from two outcrops near Suzaka is $\mathrm{N} 20^{\circ} \mathrm{E}$ in declination, as shown in Fig. 3 and if we assume the abovementioned relative movement of the land mass, this angle represents the amount of the clockwise rotation of a land mass around the vertical axis. On the contrary, the direction of the n.r.m. at Lake Suwa district is $\mathrm{N} 31^{\circ} \mathrm{W}$ in declination. This means that the land mass in this district was subjected to the anticlockwise rotation around the vertical axis.

If a northwestwards or southeastwards pushing force had acted on a place between Suzaka district and Lake Suwa district, these two districts should have rotated in different sense, the former in clockwise and the latter in anticlockwise. The existence of this kind of the force has been discussed by several author (Research group of the 
fossa magna, 1958; Ehara, 1955) and the present result supports the existence and the activity of this kind of force.

As for other three localities, that is, Tanzawa, Kofu and Shimizu Tunnel, the declination of the n.r.m. is parallel to the present dipole field. It means that either the land masses in these districts have moved only in the horizontal plane or the plutonic rocks in these districts had been intruded after the displacement of the land mass were settled, the tectonic movement having no effect on the direction of the n.r.m..

\section{Acknowledgments}

The author wishes to express his sincere thanks to Professor N. Kawai for his kind directions and valuable advices in the course of the study. His cordial thanks are also due to Professor H. Higashinaka and Professor M. Ota for their constant encouragement. He indebted to Professor Z. Hatuda who allowed the author to use A.C. demagnetizing apparatus, and to Dr. S. Kume and Dr. K. Yasukawa who kindly offered their collections of rock samples.

\section{References}

Blackett, P.M.S., J.A. Clegg, and P.H.S. Stubbs, Proc. Roy. Soc., A 256, 291, 1960.

Blundell, D.J., Geol. Mag., 98, 301, 1961.

Collinson, D.W. and S.K. Runcorn, Bull. Geol. Soc. Am., 71, 915, 1960.

Cox, A. and R.R. Doell, Bull. Geol. Soc. Am., 71, 645, 1960.

Doell, R.R. and A. Cox, Advance Geophys., 8, 221, 1691.

Ehara, S., J. Geol. Soc. Jap., 62, 289, 1956.

Irving, E., Geofis. Pura. Appl., 33, 23, 1956.

Irvnig, E. and D.H. Tarling, J. Geophys. Res., 66, 549, 1961.

Kawai, N., J. Geophys. Res., 56, 73, 1951.

Kawai, N., H. Ito, and S. Kume, Geophys. J., 6, 124, 1961.

Kawai, N., S. Kume, and H. Ito, J. Geomag. Geoelect., 13, 150, 1962.

Katada, M., Geological Map and its Explanatory Text (1:50000), "Kofu," Geol. Survey Jap. 1956 (in Japanese).

Kobayashi, T., J. Fac. Sci. Univ. Tokyo,5, 219, 1941.

Morishita, M., J. Geol. Soc. Jap., 41, 491, 1934 (in Japanese).

Omori, M., Earth Sci., 50-51, 75, 1960 (in Japanese).

Ota, R. and M. Katada, Geological Map and its Explanatory Text (1:50000), "Suzaka," Geol. Survey Jap. 1955 (in Japanese).

Research Group on the Fossa Magna, Earth Sci., 37, 29, 1958 (in Japanese).

Sawamura, K. and E. Owa, Geological Map and its Explanatory Text (1:50000), "Suwa," Geol. Survey Jap., 1953 (in Japanese).

Toyota, H., J. Geogr., 43, 522, 1931 (in Japanese). 